\title{
55. LOW-MOLECULAR-WEIGHT HYDROCARBONS IN SEDIMENTS OF DEEP SEA DRILLING PROJECT LEG 93, HOLE 603B, OFF THE EAST COAST OF NORTH AMERICA ${ }^{1}$
}

\author{
Rainer G. Schaefer and Detlev Leythaeuser, Institut für Erdöl und Organische Geochemie, Jülich²
}

\begin{abstract}
$\mathrm{C}_{2}-\mathrm{C}_{8}$ hydrocarbon concentrations (about 35 compounds identified, including saturated, aromatic, and olefinic compounds) from 27 shipboard-sealed, deep-frozen core samples of DSDP Hole 603B off the east coast of North America were determined by a gas-stripping/thermovaporization method. Total yields representing the hydrocarbons dissolved in the pore water and adsorbed on the mineral surfaces of the sediments vary from 22 to $2400 \mathrm{ng} / \mathrm{g}$ of dryweight sediment. Highest yields are measured in the two black shale samples of Core 603B-34 (hydrogen index of 360 and $320 \mathrm{mg} / \mathrm{g} \mathrm{C}_{\text {org }}$, respectively). In organic-carbon-normalized units these samples have hydrocarbon contents of 12,700 and $21,500 \mathrm{ng} / \mathrm{g} \mathrm{C}_{\text {org }}$, respectively, indicating the immaturity of their kerogens. Unusually high organic-carbonnormalized yields are associated with samples that are extremely lean in organic carbon. It is most likely that they are enriched by small amounts of migrated light hydrocarbons. This applies even to those samples with high organic-carbon contents (1.3-2.2\%) of Sections 603B-28-4, 603B-29-1, 603B-49-2, and 603B-49-3, because they have an extremely low hydrocarbon potential (hydrogen index between 40 and $60 \mathrm{mg} / \mathrm{g} \mathrm{C}_{\text {org }}$ ). Nearly all samples were found to be contaminated by varying amounts of acetone that is used routinely in large quantities on board ship during core-cutting procedures. Therefore, 48 samples from the original set of 75 collected had to be excluded from the present study.
\end{abstract}

\section{INTRODUCTION}

Hole 603B of DSDP Leg 93 was drilled in May 1983 by the crew of Glomar Challenger in $4633 \mathrm{~m}$ water depth on the lower North American continental rise $270 \mathrm{n}$. mi. east of Cape Hatteras, North Carolina $\left(35^{\circ} 29.71^{\prime} \mathrm{N}\right.$; $70^{\circ} 01.71^{\prime} \mathrm{W}$, see Fig. 1). Despite various operational problems at this site, a comprehensive sedimentary sequence was recovered which characterizes Mesozoic and late $\mathrm{Ce}$ nozoic sedimentation along this passive margin at the interface between continental and deep-sea environments.

In this chapter we analyze the low-molecular-weight hydrocarbon fraction $\left(\mathrm{C}_{2}-\mathrm{C}_{8}\right.$ molecular range) of $27 \mathrm{se}$ lected core samples from 911 to $1443 \mathrm{~m}$ sub-bottom depth to characterize the stage to which hydrocarbon-generation processes have advanced and to examine if migration effects are detectable for these compounds (cf. Leythaeuser et al., 1980, 1982, 1983).

As shown in previous studies (see, e.g., Whelan and Hunt, 1981, 1982; Schaefer et al., 1983a, b; Schaefer and Leythaeuser, 1984; Jasper et al., 1984; Schaefer et al., 1984, and references cited therein), quantity and composition of hydrocarbons of this molecular-weight range can be followed to monitor the progress of thermally controlled hydrocarbon-generation reactions and of migration processes in low-maturity sediments.

\section{METHODS}

Seventy-five core samples (approximately $10 \mathrm{~g}$ ) were stored on board in aluminum-foil sealed, $20-\mathrm{ml}$ screw-capped glass vials in a deep freezer (approximately $-20^{\circ} \mathrm{C}$ ) until the analyses were performed in the laboratory at KFA Jülich. Blank runs revealed an adequate purity

\footnotetext{
${ }^{1}$ van Hinte, J. E., Wise, S. W., Jr., et al., Init, Repts. DSDP, 93; Washington (U.S. Govt, Printing Office).

2 Address: Institut für Erdöl und Organische Geochemie, KFA Jülich GmbH, Postfach 1913. D-5170 Julich, Federal Republic of Germany.
}

of the sampling vials used for this study. The low-molecular-weight hydrocarbons (molecular range $\mathrm{C}_{2}-\mathrm{C}_{8}$ ) were determined by a slightly modified, combined gas-stripping/thermovaporization method (Schaefer et al., 1978) described in detail in our previous studies of DSDP Leg 71, 75, 79, and 89 sediments (Schaefer et al., 1983a, b; Schaefer and Leythaeuser, 1984; Schaefer et al., 1984; Schaefer and Leythaeus$\mathrm{er}$, in press). The relative standard deviation of hydrocarbon stripping yields was determined to be around $10 \%$ for core samples containing relatively low light hydrocarbon concentrations (Schaefer et al., 1978). It is assumed, however, that the standard deviation for thermovaporization yields is somewhat higher. The modification of the method (i.e., by applying a mixture of $\mathrm{CaCl}_{2}$ and silica gel to the thermovaporized hydrocarbon fraction) was necessary because nearly all samples from Hole 603B turned out to be drastically contaminated on board ship by varying amounts of acetone. Therefore, the analytical results of only 27 core samples could be included in our study.

The occurrence of large amounts of acetone, which is usually applied during core-cutting procedures on board the Glomar Challenger, in the light hydrocarbon fraction of DSDP cores causes problems because of the following two reasons. First, it is possible that the acetone used on board ship is not absolutely pure and that, therefore, other organic compounds may contaminate the core samples. Second, the acetone peak in the gas chromatograms interferes with various compounds that are of geochemical interest.

Organic-carbon contents of the sediments were measured by a combustion method (LECO Carbon Analyzer IR 112) after treatment with hot $6 \mathrm{~N} \mathrm{HCl}$ on the same samples used for low-molecular-weight hydrocarbon determination. The accuracy of the organic-carbon determination is still rather high at organic-carbon levels of $0.1 \%$ or even less ( $10 \%$ relative standard deviation). Data on kerogen type were obtained for selected whole rock samples from Hole 603B by Rock-Eval pyrolysis (Espitalié et al., 1977).

\section{RESULTS AND DISCUSSION}

\section{Organic Carbon Contents and Pyrolysis Yields}

The sample series, comprising the interval from 911 to $1443 \mathrm{~m}$ sub-bottom depth (Cores 603B-11 to 603B-68), mainly consists of silty and/or zeolite-bearing claystones or siltstones. Black carbonaceous claystones occur in Core 603B-34 (two samples). Samples 603B-28-4, 100$101 \mathrm{~cm}$ and 603B-57-5, 36-38 cm are sandstones. 


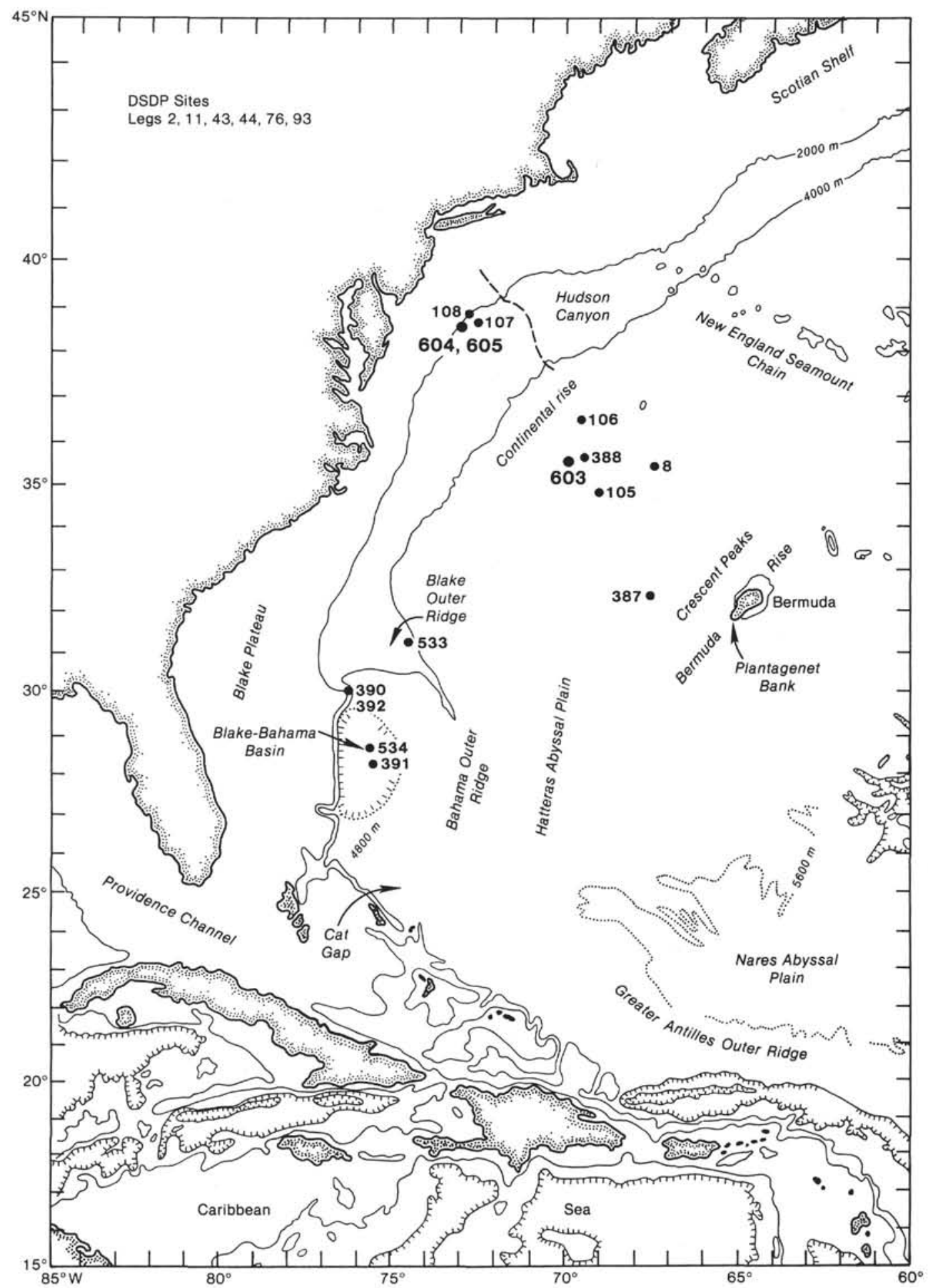

Figure 1. Location of DSDP Leg 93, Site 603.

Organic-carbon contents are very variable in the studied sample series (Table 1, Fig. 2). They range from virtually zero $(0.05 \%$ or less) in the silt- and zeolite-bearing claystones of Core 603B-29 (lower Senonian) to 8.9 and $11.1 \%$ in the black shales of Core 603B-34 (Cenomanian, 1128.02 and $1130.36 \mathrm{~m}$ depth). Elevated organic-carbon contents $(0.7-2.2 \%)$ occur in seven samples from Cores 603B-11, $-28,-29$, and -49 . All other sam- ples are relatively poor in organic carbon (between 0.1 and $0.2 \%$ ).

The results of the Rock-Eval pyrolysis (Table 1) of selected samples (organic-carbon contents higher than $0.7 \%$ ) classify the organic matter as kerogen Type III (hydrogen index $I_{H}$ less than $100 \mathrm{mg} / \mathrm{g} \mathrm{C}_{\text {org }}$ ) except for the two black shales of Core 603B-34, which exhibit a mixed type II/III kerogen quality $\left(I_{H}=357\right.$ and 323 


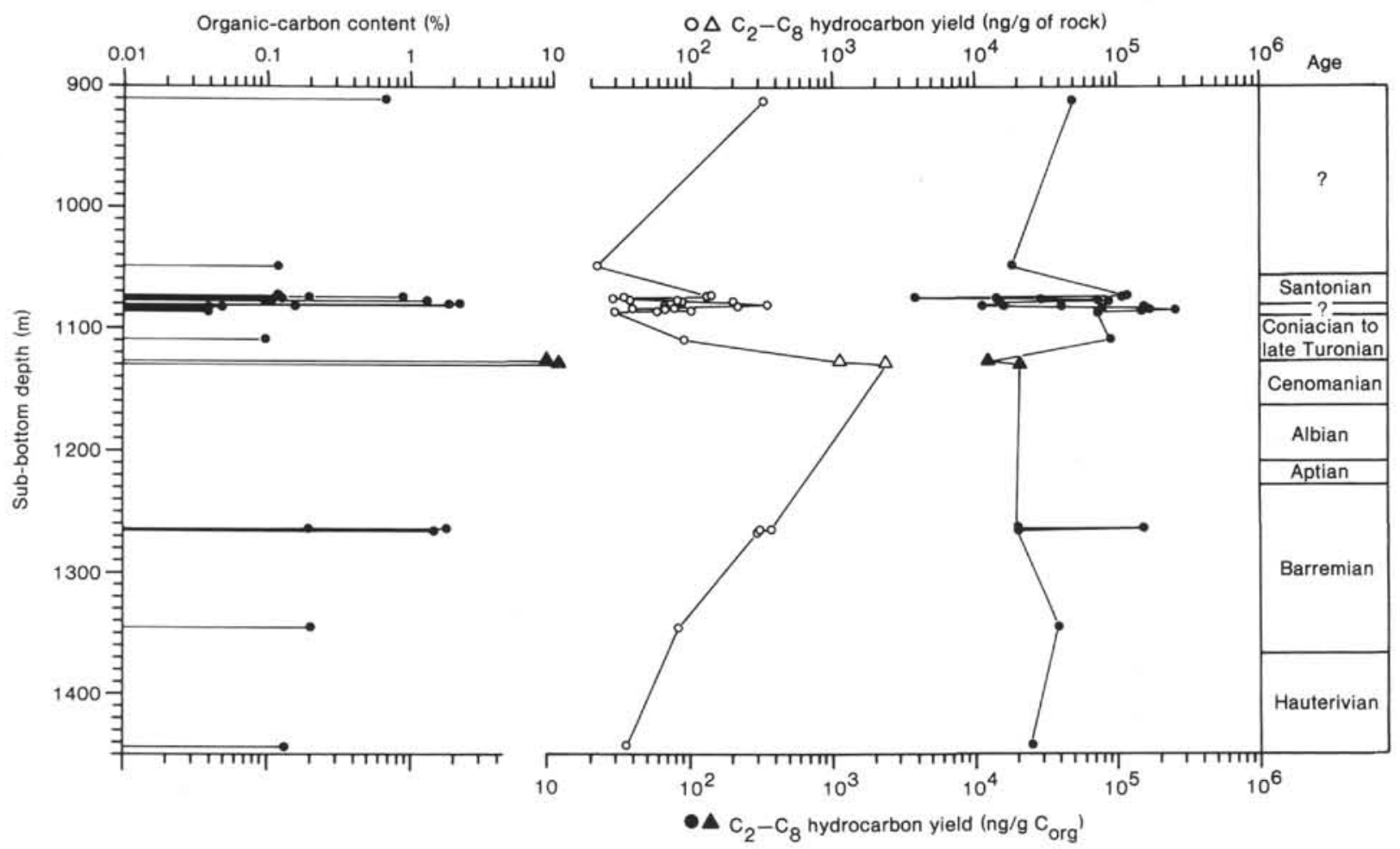

Figure 2. Organic-carbon content and low-molecular-weight hydrocarbon yield (sum of all $\mathrm{C}_{2}-\mathrm{C}_{8}$ hydrocarbons identified in Table 1, except the olefins) versus depth for sediment samples from DSDP Hole 603B, Leg 93. Triangles indicate black shale samples of Core 603B-34.

$\mathrm{mg} / \mathrm{g} \mathrm{C}_{\mathrm{org}}$, respectively). $T_{\max }$ values of these two samples are about $410^{\circ} \mathrm{C}$, indicating kerogens that are definitely in an immature evolutionary stage. $T_{\max }$ values in all other samples are quite variable (between 422 and $471^{\circ} \mathrm{C}$ ). The high values of about $470^{\circ} \mathrm{C}$ are associated with very hydrogen lean kerogens $\left(I_{H}\right.$ between 36 and $60 \mathrm{mg} / \mathrm{g} \mathrm{C}_{\text {org }}$ ) in Cores 603B-28 and -29 that are lithologically described as sandstone and silty claystones (turbidites). It is questionable, however, whether the high $T_{\max }$ values are indicative of a high maturity of these samples, because their pyrolytic yields are very low and $T_{\max }$ values may therefore be caused by an artifact effect.

\section{Light Hydrocarbon Contents}

As shown in Figure 2, light hydrocarbon yields (sum of total $\mathrm{C}_{2}-\mathrm{C}_{8}$ molecular range, see Table 1 , except the olefins) are quite variable in the samples studied . Rockweight-based values vary by more than two orders of magnitude from 22 (Sample 603B-25-2, 36-37 cm) to nearly $2400 \mathrm{ng} / \mathrm{g}$ dry-weight sediment in the black shale Sample 603B-34-2, 135-137 cm, reflecting the different potential for generating light hydrocarbons in terms of organic richness and hydrogen content of the kerogens. As expected, such high light hydrocarbon yields, as in the two black shale samples (i.e., 1130 and $2390 \mathrm{ng} / \mathrm{g}$ of rock) are not reached by any other sample of the series. Organic-carbon-rich, type-III kerogen-bearing samples $\left(\mathrm{C}_{\mathrm{org}}\right.$ content between 1.3 and $\left.2.2 \%\right)$ have yields of about 200 to $360 \mathrm{ng} / \mathrm{g}$ rock. In all other samples (with the exception of Samples 603B-11-2, 67-68 cm; 603B-28-1,
$35-36 \mathrm{~cm}$, and 603B-28-1 100-101 cm) light hydrocarbon yields are about or less than $100 \mathrm{ng} / \mathrm{g}$ of rock.

Organic-carbon-normalized yields are again very variable (i.e., by about two orders of magnitude). Highest values of more than $10^{5} \mathrm{ng} / \mathrm{g} \mathrm{C}_{\text {org }}$ occur in samples with very low organic-carbon contents $(0.04-0.2 \%)$. The two black shale samples of Core 603B-34 exhibit much lower yields of 12,700 and $21,500 \mathrm{ng} / \mathrm{g} \mathrm{C}_{\mathrm{org}}$, respectively. Provided that these hydrocarbon contents are indigenous, the conclusion is warranted that the organic matter of the black shales is immature. According to Rullkötter et al. (this volume), Cenomanian-age sediments at Site 603 have a vitrinite reflectance of about $0.3 \%$, which supports our conclusion. Concentration values of about 2 $\times 10^{4} \mathrm{ng} / \mathrm{g} \mathrm{C}_{\text {org }}$ compare well with those of corresponding Cenomanian-age black shale samples of DSDP Hole 530A of Leg 75 (Angola Basin, cf. Schaefer and Leythaeuser, 1984) where a slightly higher vitrinite reflectance (about $0.4 \%$ ) was measured (Rullkötter et al., 1984).

\section{Redistribution of Light Hydrocarbons}

To detect samples or intervals that are enriched in hydrocarbons, in Figure 3 we plotted the total light hydrocarbon yields in (A) rock-weight and (B) organic-carbon-content-normalized units versus the organic carbon contents of the sediment samples. Based on these data and following the concepts for recognition of redistribution or migration phenomena (i.e., by comparing light hydrocarbon yields in closely spaced samples of different lithology and kerogen type or samples with equal 
Table 1. Summary of low-molecular-weight hydrocarbon yields, organic-carbon contents, and Rock-Eval pyrolysis data of core samples from DSDP Hole 603B.

\begin{tabular}{|c|c|c|c|c|c|c|c|c|}
\hline $\begin{array}{l}\text { Core-Section (interval in } \mathrm{cm} \text { ) } \\
\text { Sub-bottom depth (m) }\end{array}$ & $\begin{array}{l}11-2,67-68 \\
910.97\end{array}$ & $\begin{array}{c}25-2,36-37 \\
1049.47\end{array}$ & $\begin{array}{l}28-1,35-36 \\
1073.56\end{array}$ & $\begin{array}{c}28-1,100-101 \\
1074.21\end{array}$ & $\begin{array}{c}28-2,35-36 \\
1075.06\end{array}$ & $\begin{array}{c}28-2,100-101 \\
1075.71\end{array}$ & $\begin{array}{c}28-3,35-36 \\
1076.56\end{array}$ & $\begin{array}{c}28-3,100-101 \\
1077.21\end{array}$ \\
\hline Lithology & $\begin{array}{l}\text { Mica-bearing } \\
\text { claystone }\end{array}$ & $\begin{array}{l}\text { Silt-rich } \\
\text { claystone }\end{array}$ & $\begin{array}{l}\text { Silt-bearing } \\
\text { claystone }\end{array}$ & $\begin{array}{l}\text { Silt-bearing } \\
\text { claystone }\end{array}$ & $\begin{array}{l}\text { Silt-bearing } \\
\text { claystone }\end{array}$ & $\begin{array}{l}\text { Silt-bearing } \\
\text { claystone }\end{array}$ & $\begin{array}{l}\text { Silt-bearing } \\
\text { claystone }\end{array}$ & $\begin{array}{l}\text { Silt-bearing } \\
\text { claystone }\end{array}$ \\
\hline $\mathrm{C}_{\mathrm{org}}(\%)$ & 0.67 & 0.12 & 0.12 & 0.12 & 0.90 & 0.20 & 0.13 & 0.11 \\
\hline Hydrogen index ( $\mathrm{mg}$ hydrocarbons $/ \mathrm{g} \mathrm{C}_{\mathrm{org}}$ ) & 71 & & & & 36 & & & \\
\hline Oxygen index ( $\mathrm{mg} \mathrm{CO}_{2} / \mathrm{g} \mathrm{C}_{\mathrm{org}}$ ) & 186 & & & & 315 & & & \\
\hline$T_{\max }\left({ }^{\circ} \mathrm{C}\right)$ & 427 & & & & 470 & & & \\
\hline \multicolumn{9}{|l|}{ Hydrocarbon concentration ( $\mathrm{ng} / \mathrm{g}$ dry-weight sediment) } \\
\hline Ethene & 2.3 & 0.82 & 2.0 & 1.1 & 2.3 & 1.9 & 1.9 & 8.4 \\
\hline Ethane & 3.4 & 1.5 & 16.1 & 9.8 & 3.8 & 1.6 & 2.6 & 2.8 \\
\hline Propene & 3.5 & 2.0 & 2.9 & 6.9 & 2.8 & 1.8 & 2.2 & 16.5 \\
\hline Propane & 12.9 & 2.6 & 27.9 & 19.8 & 4.8 & 3.2 & 5.2 & 5.9 \\
\hline Methylpropane & 8.3 & 2.1 & 13.5 & 13.1 & 2.1 & 2.0 & 4.3 & 6.3 \\
\hline Methylpropene +1 -butene & 4.7 & 2.3 & 5.1 & 7.0 & 2.9 & 2.5 & 3.2 & 25.2 \\
\hline$n$-Butane & 4.8 & 1.6 & 14.3 & 10.2 & 2.9 & 2.0 & 3.1 & 4.8 \\
\hline Methylbutane & 35.0 & 1.0 & 9.4 & 8.2 & 1.5 & 1.2 & 2.0 & 1.9 \\
\hline$n$-Pentane & 75.3 & 2.0 & 8.4 & 11.2 & 3.7 & 1.7 & 2.1 & 5.7 \\
\hline 2,2-Dimethylbutane & $<0.01$ & 0.05 & $?$ & - & $?$ & 0.09 & $<0.01$ & 0.14 \\
\hline Cyclopentane & $?$ & $<0.1$ & 0.68 & $<0.1$ & $<0.1$ & $<0.1$ & $<0.1$ & 0.43 \\
\hline 2,3-Dimethylbutane & 2.5 & - & 0.21 & 0.28 & - & - & $<0.1$ & $<0.1$ \\
\hline 2-Methylpentane & $?$ & 0.30 & 2.6 & 1.9 & 0.41 & 0.29 & 0.42 & 1.2 \\
\hline 3-Methylpentane & 4.5 & 0.27 & 1.3 & 1.2 & 0.49 & 0.22 & 0.30 & $?$ \\
\hline$n$-Hexane & 10.7 & 1.4 & 5.3 & 5.5 & 2.7 & 1.4 & 1.7 & 5.8 \\
\hline Methylcyclopentane + 2,2-dimethylpentane & 12.3 & 0.27 & 1.1 & 0.90 & 0.21 & 0.30 & - & 0.88 \\
\hline 2,4-Dimethylpentane & 1.5 & - & - & $<0.1$ & - & - & - & 0.38 \\
\hline Benzene & 21.4 & 0.95 & 7.3 & 5.2 & 2.5 & 0.94 & 1.8 & 9.4 \\
\hline Cyclohexane & 10.9 & $<0.1$ & - & $<0.1$ & - & - & - & 0.40 \\
\hline 2-Methylhexane & 3.9 & 0.46 & 0.90 & 1.0 & $<0.1$ & 0.65 & $<0.1$ & 1.2 \\
\hline 2,3-Dimethylpentane + 1,1-dimethylcyclopentane & 4.0 & 0.26 & 0.38 & 0.66 & - & 0.25 & $<0.1$ & 1.1 \\
\hline 3-Methylhexane & 4.5 & 0.55 & 0.59 & 1.1 & - & 0.65 & $<0.1$ & 1.1 \\
\hline 1,cis-3-Dimethylcyclopentane & 4.8 & - & - & $<0.1$ & 0.23 & $<0.1$ & - & $?$ \\
\hline 1,trans-3-Dimethylcyclopentane & 4.6 & - & - & $<0.1$ & - & - & - & $<0.1$ \\
\hline 1,trans-2-Dimethylcyclopentane & 4.3 & - & - & $<0.1$ & - & - & - & 0.70 \\
\hline$n$-Heptane & 15.7 & 1.0 & 4.5 & 3.2 & 1.7 & 1.4 & 2.0 & 4.6 \\
\hline 1,cis-2-Dimethylcyclopentane & 1.6 & - & - & - & - & - & - & - \\
\hline Methylcyclohexane & 33.3 & - & - & $<0.1$ & - & - & - & - \\
\hline 2,5-Dimethylhexane & $<0.1$ & - & - & - & - & - & - & - \\
\hline Ethylcyclopentane & 2.2 & - & - & - & - & - & - & - \\
\hline 1,trans-2,cis-4-Trimethylcyclopentane & 0.59 & - & - & - & - & - & - & - \\
\hline 1 ,trans-2,cis-3-Trimethylcyclopentane & 1.7 & - & - & - & - & - & - & $<0.1$ \\
\hline Toluene & 39.3 & 4.9 & 27.2 & 38.6 & 5.2 & 9.8 & 11.3 & 17.6 \\
\hline n-Octane & 6.2 & $<0.1$ & 0.28 & $<0.1$ & 1.8 & 0.47 & 0.86 & 5.2 \\
\hline
\end{tabular}

Note: $-=$ value below or near detection limit; ? = value uncertain due to peak overlappng.

kerogen type at different depth levels; cf. Schaefer et al., 1983a; Schaefer and Leythaeuser, 1984; Jasper et al., 1984; Schaefer and Leythaeuser, in press), it appeared that two depth intervals should be considered in more detail.

\section{4-1087-m Depth Interval}

Organic-carbon contents and $\mathrm{C}_{2}-\mathrm{C}_{8}$ hydrocarbon yields (both rock-weight-based and normalized to organic-carbon contents of the rock) are plotted versus depth for 16 samples in Figure 4. Comparing the organic-carbon-normalized yields with those of the two hydrogen-rich-kerogen-bearing black shales of Core 603B-34 (Figs. 2 and $3 B$ ), we conclude that all samples included in Figure 4 are enriched in hydrocarbons (except Sample 603B-28-2, $35-36 \mathrm{~cm}$ ). In view of the extremely low hydrocarbon potential, even the yields of the three samples with high organic-carbon contents from 1078.71, 1081.11, and $1081.81 \mathrm{~m}$ depth are much higher than expected at this maturity level $\left(15,400 ; 16,100 ; 11,600 \mathrm{ng} / \mathrm{g} \mathrm{C}_{\text {org }}\right)$. In this respect it is very unlikely that these samples are the source of the hydrocarbon impregnation of the other organiccarbon-lean samples of this interval. Instead, we believe that possible sources for these hydrocarbons are hydro- gen-rich-kerogen-bearing claystones, such as the black shales of Core 603B-34. To support this hypothesis we plotted the rock-weight-based yields of three $n$-alkanes (ethane, propane, $n$-butane) for this depth interval (Fig. $5)$. As can be seen in this figure, there is no clear relationship between hydrocarbon yields, molecular size, and organic richness of the rocks. Compare, for instance, the hydrocarbon yields of the organic-carbon-rich samples $\left(1.3-2.2 \% C_{\text {org }}\right)$ with those of only $0.04 \% C_{\text {org }}$ at $1084.81,1085.61$, and $1086.31 \mathrm{~m}$ depth; their hydrocarbon yields are quite similar. The most probable explanation for this observation is to assume that hydrocarbons have been redistributed within the sedimentary column. The degree of enrichment at any given level would be controlled by adsorption phenomena of the mineral surfaces and the available pore space of the rock.

\section{4-1266-m Depth Interval}

Three samples with organic-carbon contents of 1.8 , 0.2 , and $1.5 \%$ are considered. In particular, the first two closely spaced samples (only $8 \mathrm{~cm}$ apart) represent an ideal pair to examine potential redistribution effects. It is obvious from Figure 2 that total light hydrocarbon yields in rock-weight-based units are very similar in these 
Table 1 (continued).

\begin{tabular}{|c|c|c|c|c|c|c|c|c|c|c|}
\hline $\begin{array}{c}28-4,35-36 \\
1078.06\end{array}$ & $\begin{array}{c}28-4,100-101 \\
1078.71\end{array}$ & $\begin{array}{c}29-1,31-32 \\
1081.11\end{array}$ & $\begin{array}{c}29-1,100-101 \\
1081.81\end{array}$ & $\begin{array}{c}29-2,31-32 \\
1082.61\end{array}$ & $\begin{array}{c}29-2,100-101 \\
1083.31 \\
\text { Silt- and } \\
\text { zeolite- } \\
\text { bearing } \\
\text { claystone }\end{array}$ & $\begin{array}{c}29-3,31-32 \\
1084.11 \\
\text { Silt- and } \\
\text { zeolite- } \\
\text { bearing } \\
\text { claystone }\end{array}$ & $\begin{array}{c}\text { 29-3, 100-101 } \\
1084.81 \\
\text { Silt- and } \\
\text { zeolite- } \\
\text { bearing } \\
\text { claystone }\end{array}$ & $\begin{array}{c}29-4,31-32 \\
1085.61 \\
\text { Silt- and } \\
\text { zeolite- } \\
\text { bearing } \\
\text { claystone }\end{array}$ & $\begin{array}{c}29-4,100-101 \\
1086.31 \\
\text { Silt- and } \\
\text { zeolite- } \\
\text { bearing } \\
\text { claystone }\end{array}$ & $\begin{array}{c}29-5,31-32 \\
1087.11 \\
\text { Silt- and } \\
\text { zeolite- } \\
\text { bearing } \\
\text { claystone }\end{array}$ \\
\hline 0.10 & $\begin{array}{l}1.33 \\
60 \\
65 \\
471\end{array}$ & $\begin{array}{l}2.22 \\
40 \\
58 \\
471\end{array}$ & $\begin{array}{l}1.90 \\
48 \\
49 \\
470\end{array}$ & 0.16 & 0.05 & 0.05 & 0.04 & 0.04 & 0.04 & 0.04 \\
\hline
\end{tabular}

\begin{tabular}{cc}
2.3 & 3.4 \\
2.3 & 6.8 \\
3.3 & 4.6 \\
13.2 & 12.5 \\
8.5 & 8.7 \\
5.0 & 4.3 \\
7.0 & 6.6 \\
5.6 & 8.8 \\
4.2 & 23.5 \\
0.05 & 0.12 \\
$<0.1$ & $?$ \\
0.23 & - \\
1.4 & 2.4 \\
0.87 & 1.3 \\
3.4 & 4.8 \\
0.66 & 1.2 \\
- & 0.21 \\
6.0 & 10.5 \\
$<0.1$ & 0.78 \\
1.1 & 1.5 \\
0.48 & 0.94 \\
1.0 & 1.8 \\
0.41 & 0.49 \\
- & 0.43 \\
\hline- & 0.32 \\
3.4 & 4.6 \\
- & $<0.1$ \\
- & 2.1 \\
- & - \\
- & $<0.1$ \\
- & - \\
- & - \\
28.0 & 103.0 \\
$<0.1$ & $<0.1$ \\
\hline & \\
\hline &
\end{tabular}

$\begin{array}{cc}5.2 & 2.3 \\ 4.3 & 5 . \\ 6.9 & 4.3 \\ 6.9 & 15 . \\ 4.0 & 6.6 \\ 6.3 & 4.9 \\ 4.6 & 8.3 \\ 10.3 & 8 . \\ 53.7 & 30 . \\ 3.7 & 0 . \\ <0.1 & <0 . \\ <0.1 & 0 . \\ 2.9 & 2 . \\ 2.4 & 0.92 \\ 7.8 & 5.3 \\ 2.1 & 1.3 \\ 0.30 & 0.20 \\ 19.6 & 20.4 \\ 2.2 & 1 . \\ 2.5 & 1.3 \\ 2.2 & 1 . \\ 3.7 & 1.7 \\ 2.5 & 0.74 \\ 0.95 & 0.33 \\ 1.0 & 0.44 \\ 7.3 & 4.7 \\ 0.54 & - \\ 7.4 & 2.4 \\ <0.1 & - \\ 0.11 & - \\ <0.1 & <0.1 \\ <0.1 & 96.0 \\ 199.0 & 2.0 \\ 4.4 & \end{array}$

\begin{tabular}{cc}
2.3 & 1.7 \\
5.6 & 11.4 \\
4.3 & 2.5 \\
15.8 & 14.6 \\
6.6 & 4.6 \\
4.9 & 3.0 \\
8.3 & 6.3 \\
8.7 & 2.5 \\
30.6 & 4.4 \\
0.23 & $<0.01$ \\
$<0.1$ & 0.26 \\
0.26 & $<0.1$ \\
2.2 & 0.70 \\
0.92 & 0.55 \\
5.3 & 3.2 \\
1.3 & 0.61 \\
0.20 & 0.12 \\
20.4 & 3.4 \\
1.0 & $<0.1$ \\
1.3 & 0.94 \\
1.1 & 0.32 \\
1.7 & 1.0 \\
0.74 & $<0.1$ \\
0.33 & $<0.1$ \\
0.44 & $<0.1$ \\
4.7 & 3.0 \\
\hline 2.4 & - \\
- & - \\
- & - \\
$<0.1$ & - \\
96.0 & - \\
2.0 & $<.6$ \\
& $<0.1$ \\
\hline &
\end{tabular}

\begin{tabular}{c}
2.1 \\
4.8 \\
3.4 \\
12.1 \\
6.4 \\
4.6 \\
6.5 \\
4.3 \\
2.9 \\
0.07 \\
$<0.1$ \\
$\overline{0.82}$ \\
0.46 \\
2.5 \\
0.41 \\
$\overline{5} .2$ \\
\hline- \\
$<.47$ \\
$<0.1$ \\
$<0.1$ \\
\hline- \\
\hline 2.5 \\
\hline- \\
\hline- \\
- \\
\hline- \\
$<7.7$ \\
$<0.1$ \\
\hline
\end{tabular}
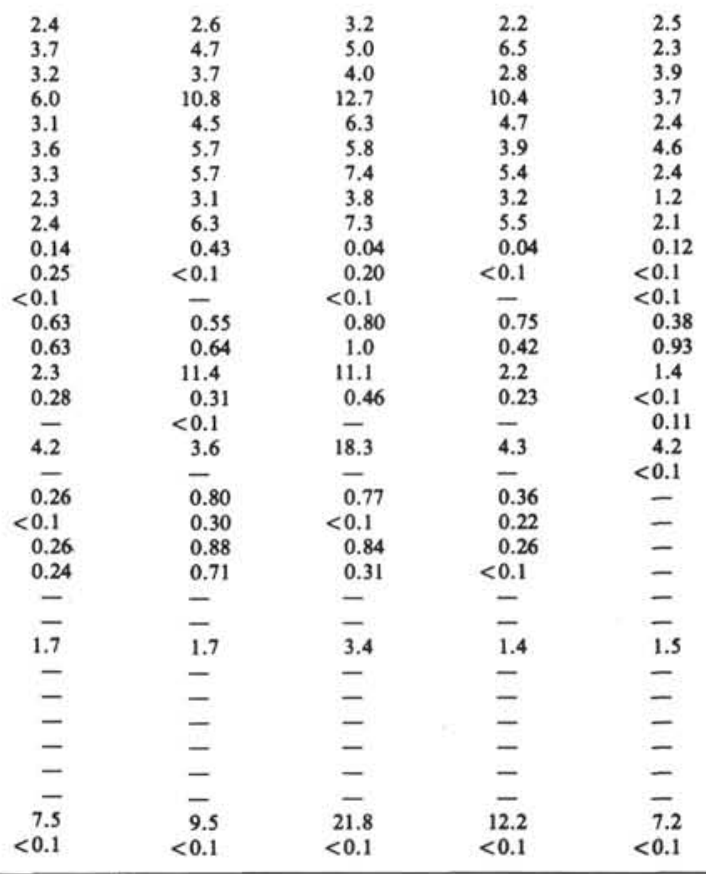

three samples (376, 315, and $305 \mathrm{ng} / \mathrm{g}$ of rock). Likewise, the organic-carbon-normalized values vary from

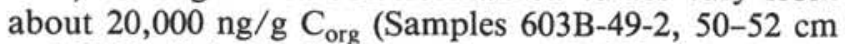
and $603 \mathrm{~B}-49-3,64-66 \mathrm{~cm}$ ) to about $160,000 \mathrm{ng} / \mathrm{g} \mathrm{C}_{\mathrm{org}}$ in the siltstone with only $0.2 \%$ of organic carbon $(603 \mathrm{~B}$ 49-2, 58-61 cm). It appears that these three samples are, in terms of their total light hydrocarbon contents, equilibrated to a certain extent by a redistribution process. However, an examination of individual compounds (see Table 1) in Sample 603B-49-2, 50-52 cm $\left(\mathrm{C}_{\text {org }}=1.8 \%\right)$ and Sample 603B-49-2, 58-61 cm $\left(\mathrm{C}_{\text {org }}=0.2 \%\right)$ reveals that the $\mathrm{C}_{2}-\mathrm{C}_{4}$ hydrocarbons are more abundant in the latter, whereas $\mathrm{C}_{5}-\mathrm{C}_{7}$ hydrocarbon yields are higher in the former. In this respect it is questionable if these data reflect simple equilibration of the compounds between the sediment layers. Instead, the general predominance of the gaseous hydrocarbons in Sample 603B-49-2, 58$61 \mathrm{~cm}$ might be caused by preferential diffusion of the most mobile compounds into this layer. On the other hand, in view of the significant difference in organiccarbon contents of these two samples by nearly one order of magnitude, it is not surprising that the concentrations of individual hydrocarbons, particularly in the $\mathrm{C}_{5}-\mathrm{C}_{7}$ molecular range, are not identical in both sam- ples. This might, for instance be caused by different adsorption activities of their organic matter and mineral surfaces.

As discussed before, however, even $\mathrm{C}_{2}-\mathrm{C}_{8}$ hydrocarbon yields of $20,000 \mathrm{ng} / \mathrm{g} \mathrm{C}_{\text {org }}$ are much too high in view of the extremely low hydrocarbon potential of the two organic-carbon-rich samples (hydrogen index 49 and $44 \mathrm{mg} / \mathrm{g} \mathrm{C}_{\text {org }}$, respectively) at the corresponding maturity level. Again, as concluded from the results in the 1074-1087-m depth interval, the source of the hydrocarbons that caused the enrichment is most probably hydrogen-rich-kerogen-bearing claystones such as black shales from Core 603B-34.

\section{CONCLUSIONS}

The conclusions reached in this study were of a somewhat limited nature because after all samples received were analyzed, only 27 samples yielded reliable data that could be included in this interpretation. This was because of the severe acetone contamination of most samples. It is emphasized, however, that even for these 27 samples the quality of the data is not ideal. Therefore, the conclusions drawn here are mainly based on total $\mathrm{C}_{2}-\mathrm{C}_{8}$ hydrocarbon yields. 
Table 1 (continued).

\begin{tabular}{|c|c|c|c|c|c|c|c|c|}
\hline $\begin{array}{l}\text { Core-Section (interval in cm) } \\
\text { Sub-bottom depth (m) }\end{array}$ & $\begin{array}{c}32-2,53-54 \\
1109.50\end{array}$ & $\begin{array}{l}34-1,51-53 \\
1128.02\end{array}$ & $\begin{array}{c}34-2,135-137 \\
1130.36\end{array}$ & $\begin{array}{c}49-2,50-52 \\
1264.41\end{array}$ & $\begin{array}{c}49-2,58-61 \\
1264.49\end{array}$ & $\begin{array}{c}49-3,64-66 \\
1266.05\end{array}$ & $\begin{array}{c}57-5,36-38 \\
1345.57\end{array}$ & $\begin{array}{c}68-2,10-11 \\
1443.31\end{array}$ \\
\hline Lithology & $\begin{array}{c}\text { Silt-rich } \\
\text { claystone }\end{array}$ & $\begin{array}{c}\text { Black } \\
\text { carbonaceous } \\
\text { claystone }\end{array}$ & $\begin{array}{c}\text { Black } \\
\text { carbonaceous } \\
\text { claystone }\end{array}$ & Siltstone & Siltstone & $\begin{array}{l}\text { Nannofossil- } \\
\text { rich } \\
\text { claystone }\end{array}$ & Sandstone & $\begin{array}{l}\text { Sandy } \\
\text { siltstone }\end{array}$ \\
\hline $\mathrm{C}_{\mathrm{org}}(\%)$ & 0.10 & 8.94 & 11.10 & 1.83 & 0.20 & 1.49 & 0.21 & 0.14 \\
\hline Hydrogen index ( $\mathrm{mg}$ hydrocarbons $/ \mathrm{g} \mathrm{C}_{\text {org }}$ ) & & 357 & 323 & 49 & & 44 & & \\
\hline Oxygen index $\left(\mathrm{mg} \mathrm{CO}_{2} / \mathrm{g} \mathrm{C}_{\mathrm{org}}\right)$ & & 67 & 64 & 161 & & 156 & & \\
\hline$T_{\max }\left({ }^{\circ} \mathrm{C}\right)$ & & 409 & 412 & 423 & & 422 & & \\
\hline \multicolumn{9}{|l|}{ Hydrocarbon concentration (ng/g dry-weight sediment) } \\
\hline Ethene & 2.3 & 15.2 & 39.2 & 5.8 & 6.1 & 6.1 & 2.4 & 0.89 \\
\hline Ethane & 5.1 & 103.0 & 55.8 & 23.0 & 52.6 & 17.9 & 9.8 & 4.4 \\
\hline Propene & 2.7 & 12.9 & 33.3 & 7.3 & 10.5 & 9.5 & 3.9 & 1.3 \\
\hline Propane & 12.6 & 109.0 & 87.9 & 23.7 & 61.4 & 16.6 & 12.0 & 4.6 \\
\hline Methylpropane & 6.1 & 141.0 & 95.7 & 8.6 & 27.8 & 9.2 & 6.2 & 2.4 \\
\hline Methylpropene + 1-butene & 4.3 & 7.7 & 14.1 & 4.0 & 6.9 & 5.9 & 3.9 & 1.3 \\
\hline$n$-Butane & 6.4 & 35.3 & 39.9 & 12.5 & 35.0 & 8.5 & 6.5 & 2.7 \\
\hline Methylbutane & 3.8 & $?$ & 251.0 & 23.0 & 18.8 & 24.6 & 5.2 & 1.7 \\
\hline$n$-Pentane & 3.1 & 81.4 & 443.0 & 89.4 & 23.2 & 89.4 & 5.4 & 2.3 \\
\hline 2,2-Dimethylbutane & $<0.01$ & 2.3 & 9.2 & $?$ & 0.20 & 0.53 & 0.41 & 0.07 \\
\hline Cyclopentane & $<0.1$ & 44.4 & 407.0 & $<0.1$ & 2.9 & $?$ & 0.70 & 0.22 \\
\hline 2,3-Dimethylbutane & - & - & 12.7 & - & 0.81 & 1.2 & 0.28 & $<0.1$ \\
\hline 2-Methylpentane & 0.83 & 110.0 & 140.0 & 6.3 & 4.9 & 5.3 & 1.6 & 0.69 \\
\hline 3-Methylpentane & 0.71 & 16.1 & 21.9 & 4.2 & 3.4 & 2.6 & 1.1 & 0.42 \\
\hline$n$-Hexane & 3.1 & 21.7 & 50.1 & 70.4 & 13.6 & 11.2 & 3.9 & 1.7 \\
\hline Methylcyclopentane + 2,2-dimethylpentane & 1.2 & 114.0 & 129.0 & 7.1 & 2.9 & 10.4 & 1.7 & $<0.1$ \\
\hline 2,4-Dimethylpentane & 0.40 & 8.5 & 10.3 & - & - & 0.51 & - & - \\
\hline Benzene & 5.6 & 16.1 & 33.1 & 10.0 & 10.3 & 7.4 & 3.4 & 2.7 \\
\hline Cyclohexane & 0.30 & 10.0 & 24.1 & 6.0 & 0.60 & 4.5 & 0.65 & 0.15 \\
\hline 2-Methylhexane & 3.2 & 12.6 & 22.7 & 2.6 & 2.1 & 2.3 & 0.64 & 0.47 \\
\hline 2,3-Dimethylpentane + 1,1-dimethylcyclopentane & 1.2 & 30.3 & 46.3 & 2.7 & 0.95 & 2.9 & 0.32 & 0.32 \\
\hline 3-Methylhexane & 3.7 & 10.9 & 25.1 & 3.5 & 2.0 & 3.3 & 0.68 & 0.53 \\
\hline 1,cis-3-Dimethylcyclopentane & 0.24 & 53.2 & 81.1 & 1.9 & 0.68 & 2.3 & 0.30 & 0.37 \\
\hline 1,trans-3-Dimethylcyclopentane & 0.40 & 41.1 & 57.1 & 2.0 & 0.48 & 2.7 & 0.28 & $<0.1$ \\
\hline 1,trans-2-Dimethylcyclopentane & 0.20 & 20.0 & 29.9 & 2.3 & 1.5 & 14.9 & 0.60 & 0.34 \\
\hline$n$-Heptane & 3.5 & 17.5 & 40.1 & 6.5 & 7.8 & 6.1 & 2.6 & 1.5 \\
\hline 1,cis-2-Dimethylcyclopentane & - & 19.7 & 27.7 & 0.32 & $<0.1$ & 1.2 & - & - \\
\hline Methylcyclohexane & $<0.1$ & 36.7 & 69.1 & 11.2 & 0.72 & $<0.1$ & 0.85 & 0.59 \\
\hline 2,5-Dimethylhexane & - & 3.6 & $<0.1$ & - & - & - & - & - \\
\hline Ethylcyclopentane & - & 19.0 & 28.2 & 0.32 & $<0.1$ & - & - & - \\
\hline 1,trans-2,cis-4-Trimethylcyclopentane & - & 16.5 & 16.0 & 1.3 & $<0.1$ & 5.5 & - & - \\
\hline 1,trans-2,cis-3-Trimethylcyclopentane & - & 4.7 & 3.6 & 5.4 & $<0.1$ & 9.6 & - & - \\
\hline Toluene & 29.3 & 21.8 & 120.0 & 52.1 & 36.5 & 42.8 & 17.0 & 7.7 \\
\hline$n$-Octane & $<0.1$ & 9.8 & 7.3 & $<0.1$ & 0.14 & $<0.1$ & 1.4 & $<0.1$ \\
\hline
\end{tabular}

1. Highest rock-weight-based $\mathrm{C}_{2}-\mathrm{C}_{8}$ hydrocarbon yields are measured in the two black shale samples of Core 603B-34 (1130 and $2390 \mathrm{ng} / \mathrm{g}$ of rock). The corresponding organic-carbon-normalized values $(12,700$ and $21,500 \mathrm{ng} / \mathrm{g} \mathrm{C}_{\text {org }}$ ) are typical for indigenous concentration levels of immature hydrogen-rich-kerogen-bearing claystones. Similar values were measured, for instance, in corresponding Cenomanian-age black shales of DSDP Hole 530A (Angola Basin).

2. Organic-carbon-normalized yields of most other samples of this study are of similar magnitude or even higher despite greatly inferior kerogen qualities.

The highest yields occur in samples with 0.2 or less organic-carbon contents (more than $10^{5} \mathrm{ng} / \mathrm{g} \mathrm{C}_{\text {org }}$ ). It is most likely that they are enriched with small amounts of low-molecular-weight hydrocarbons. Because of their very low organic-carbon contents, the organic-carbon-normalized values indicate in an extremely sensitive fashion even traces of migrated hydrocarbons. On the other hand, it could be shown that even samples richer in organic carbon and bearing Type III kerogen (603B-28-4, 100-101 $\mathrm{cm}$; 603B-29-1, 31-32 cm; 603B-29-1, 100-101 cm; 603B$49-2,50-52 \mathrm{~cm}$; and 603B-49-3, 64-66 cm) are also enriched in hydrocarbons that were generated in potential hydrocarbon sources, such as the black shales of Core 603B-34.

\section{ACKNOWLEDGMENTS}

We gratefully acknowledge the sample supply from the U.S. National Science Foundation and the financial support of the Deutsche Forschungsgemeinschaft, Schwerpunkt "Deep Sea Drilling Project" (DFG Grant No. Le 469/1).

We would like to thank Dr. P. J. Müller for the organic carbon and Rock-Eval pyrolysis data. Technical assistance by Miss E. Biermanns and Messrs. U. Disko, H. Hardelauf, M. Landgraf, and H.-G. Sittardt (all at KFA Jülich) is gratefully appreciated. Miss U. Fix typed the manuscript.

\section{REFERENCES}

Espitalié, J., Laporte, J. L., Madec, M., Marquis, F., Leplat, P., Paulet, J., and Boutefeu, A., 1977. Méthode rapide de caractérisation des roches mères, de leur potentiel pétrolier et de leur degré d'évolution. Rev. Inst. Fr. Pet., 32:23-42.

Jasper, J. P., Whelan, J. K., and Hunt, J. M., 1984. Migration of $C_{1}$ to $\mathrm{C}_{8}$ volatile organic compounds in sediments from the Deep Sea Drilling Project, Leg 75, Hole 530A. In Hay, W. W., Sibuet, J.-C., et al., Init. Repts. DSDP, 75, Pt. 2: Washington (U.S. Govt. Printing Office), 1001-1008.

Leythaeuser, D., Schaefer, R. G., and Pooch, H., 1983. Diffusion of light hydrocarbons in subsurface sedimentary rocks. Am. Assoc. Pet. Geol. Bull., 67:889-895. 
Leythaeuser, D., Schaefer, R. G., and Yükler, A., 1980. Diffusion of light hydrocarbons through near-surface rocks. Nature (London) 284:522-525.

1982. Role of diffusion in primary migration of hydrocarbons. Am. Assoc. Pet. Geol. Bull., 66:408-429.

Rullkötter, J., Mukhopadhyay, P. K., and Welte, D. H., 1984. Geochemistry and petrography of organic matter in sediments from Hole 530A, Angola Basin, and Hole 532, Walvis Ridge, Deep Sea Drilling Project. In Hay, W. W., Sibuet, J.-C., et al., Init. Repts. DSDP, 75, Pt. 2: Washington (U.S. Govt. Printing Office), 10691087.

Schaefer, R. G., and Leythaeuser, D., 1984. $\mathrm{C}_{2}-\mathrm{C}_{8}$ Hydrocarbons in sediments from Deep Sea Drilling Project Leg 75, Holes 503A, Angola Basin, and 532, Walvis Ridge. In Hay, W. W., Sibuet, J.-C., et al., Init. Repts. DSDP, 75, Pt. 2: Washington (U.S. Govt. Printing Office), $1055-1067$.

, in press. Low molecular weight hydrocarbons in sediments of Deep Sea Drilling Project Leg 89, Sites 585, East Mariana Basin, and 586, Ontong-Java Plateau. In Moberly, R., Schlanger, S. O., et al., Init. Repts. DSDP, 89: Washington (U.S. Govt. Printing Office), 577-588.

Schaefer, R. G., Leythaeuser, D., and Gormly, J., 1984. Generation and migration of low-molecular-weight hydrocarbons in sediments of Deep Sea Drilling Project Leg 79, Sites 544, 545, and 547, offshore Morocco. In Hinz, K., Winterer, E. L., et al., Init. Repts. DSDP, 79: Washington (U.S. Govt. Printing Office), 743-773.

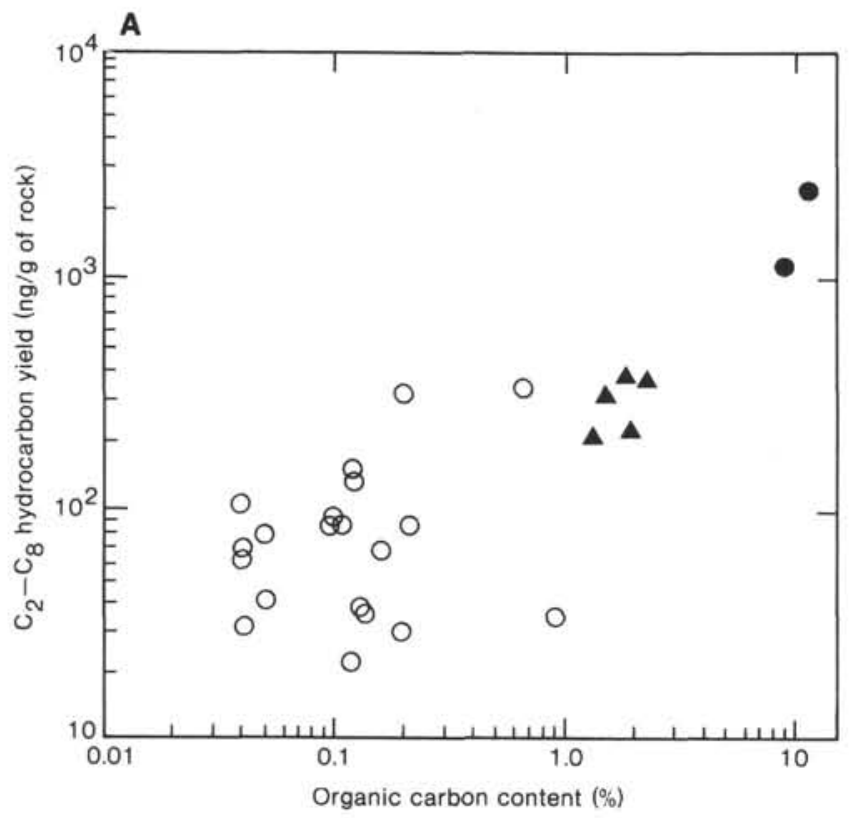

Schaefer, R. G., Leythaeuser, D., and von der Dick, H., 1983a. Generation and migration of low-molecular-weight hydrocarbons in sediments from Site 511 of DSDP/IPOD Leg 71, Falkland Plateau, South Atlantic. In Bjorøy, M., et al. (Eds.), Advances in Organic Geochemistry 1981: Chichester (Wiley), pp. 164-174.

Schaefer, R. G., von der Dick, H., and Leythaeuser, D., 1983b. $\mathrm{C}_{2}-\mathrm{C}_{8}$ Hydrocarbons in sediments from Deep Sea Drilling Project Leg 71, Site 511, Falkland Plateau, South Atlantic. In Ludwig, W. J., Krasheninnikov, V., et al., Init. Repts. DSDP, 71: Washington (U.S. Govt. Printing Office), 1033-1043.

Schaefer, R. G., Weiner, B., and Leythaeuser, D., 1978. Determination of sub-nanogram per gram quantities of light hydrocarbons $\left(\mathrm{C}_{2}-\mathrm{C}_{9}\right)$ in rock samples by hydrogen stripping in the flow system of a capillary gas chromatograph. Anal. Chem., 50:1848-1854.

Whelan, J. K., and Hunt, J. M., 1981. $\mathrm{C}_{1}-\mathrm{C}_{8}$ Hydrocarbons in Leg 63 sediments from outer California and Baja California borderlands. In Yeats, R. S., Haq, B. U., et al., Init. Repts. DSDP, 63: Washington (U.S. Govt. Printing Office), 775-784.

1982. $\mathrm{C}_{1}-\mathrm{C}_{8}$ Hydrocarbons in Leg 64 sediments, Gulf of California. In Curray, J. R., Moore, D. G., et al., Init. Repts. DSDP, 64, Pt. 2: Washington (U.S. Govt. Printing Office), 763780 .

Date of Initial Receipt: 20 May 1985

Date of Acceptance: 13 December 1985

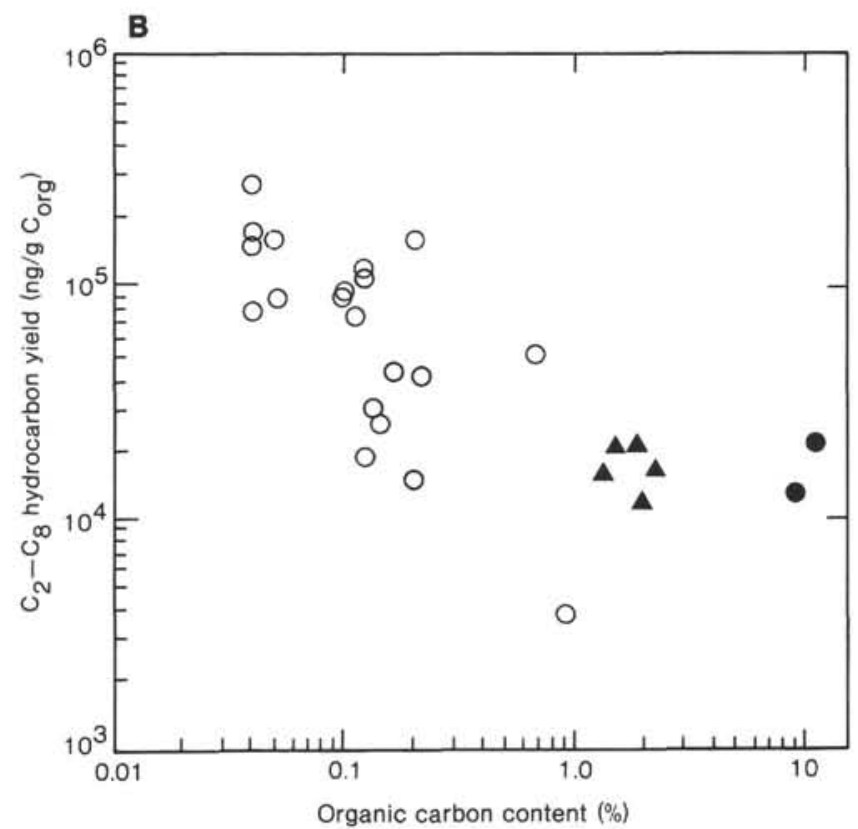

Figure 3. Low-molecular-weight hydrocarbon yield (A) in rock-weight and (B) in organic-carbon-content-normalized units, versus organic-carbon content of the sediment samples from DSDP Hole 603B, Leg 93. Solid circles indicate black shale samples of Core 603B-34. Triangles indicate samples with high organic-carbon contents $(1.3-2.2 \%)$ of Cores 603B-28, -29 , and -49 . 


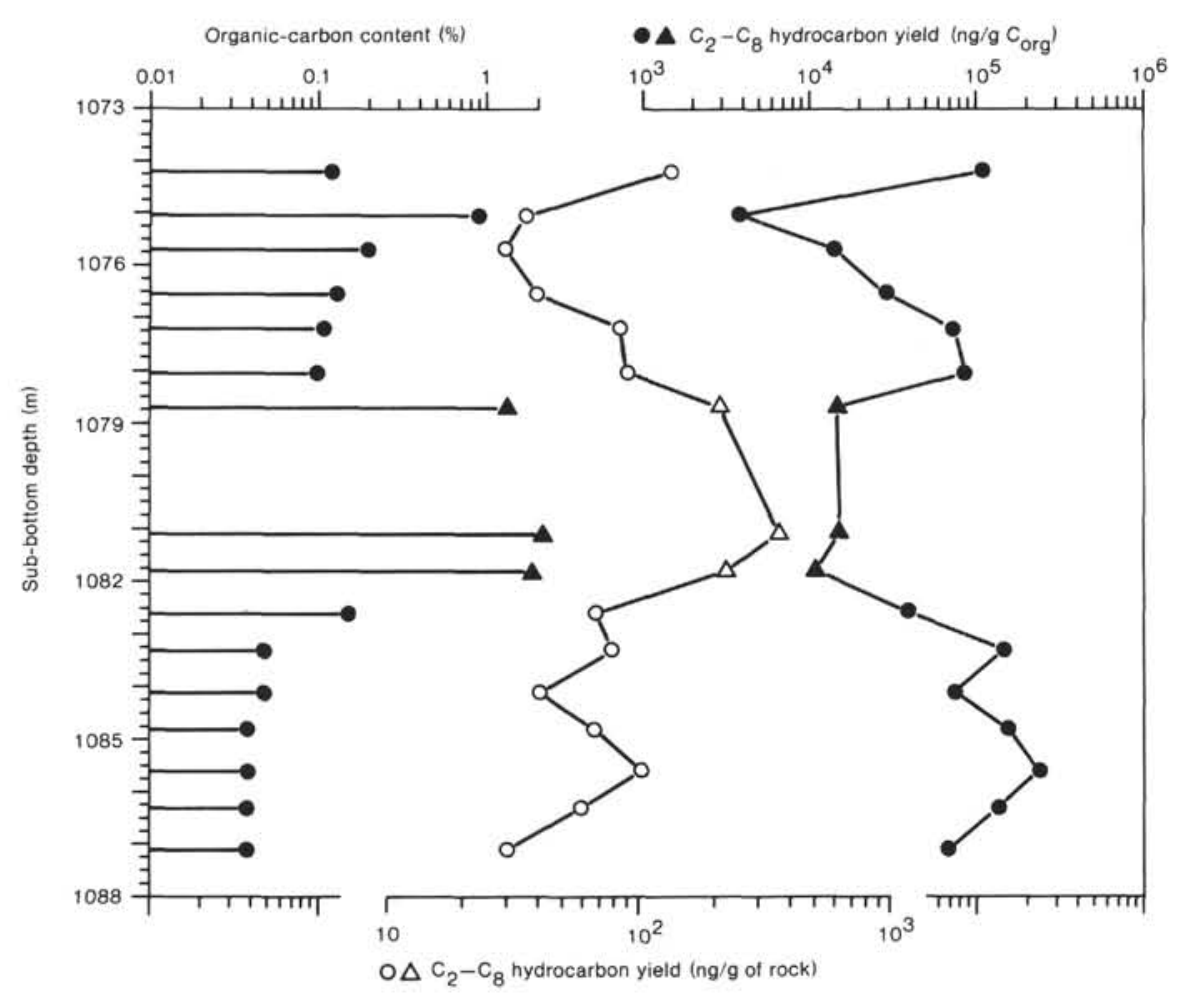

Figure 4. Organic-carbon content and low-molecular-weight hydrocarbon yield (as in Fig. 2) versus depth for the 1074-1087-m interval of DSDP Hole 603B, Leg 93. Triangles indicate samples with high organic-carbon contents (1.3-2.2\%) of Cores 603B-28 and -29 .

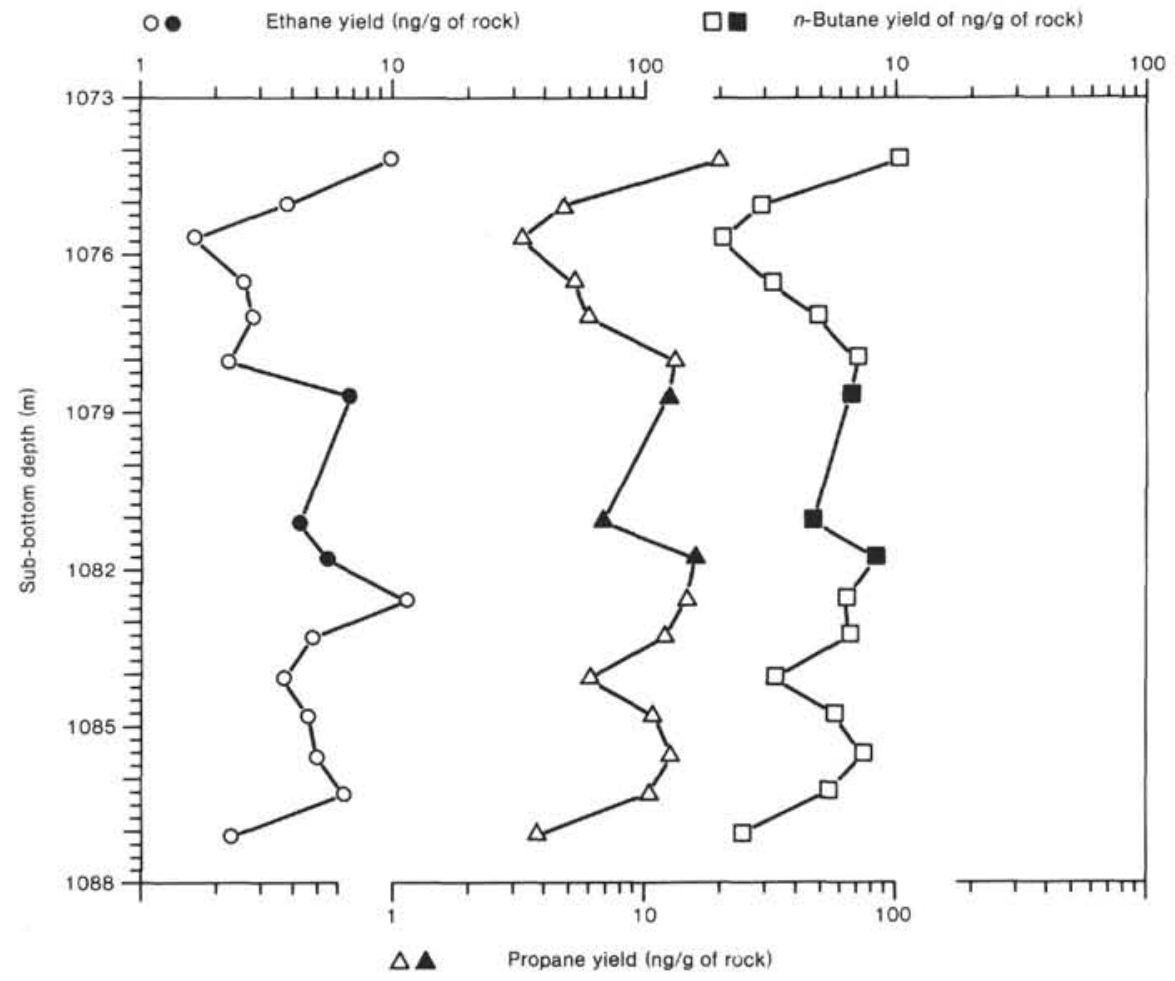

Figure 5. Ethane, propane, and $n$-butane yield (ng/g dry-weight sediment) versus depth for the 1074-1087-m interval of DSDP Hole 603B, Leg 93. Solid symbols indicate samples with high organic-carbon contents (1.3-2.2\%) of Cores 603B-28 and -29. 